\title{
Alfalfa Leaves as a Protein Source. Replacement Value of Alfalfa Leaves for Soybean Meal Protein in Forage-based Diets Fed to Mature Ewes
}

http://dx.doi.org/10.4314/sajest.v2i2.39818

Tsopito C. M. ${ }^{1 *}$, Hess B. W' ${ }^{2}$ Gray A. $M^{3}$, and Rule D. C. ${ }^{2}$

${ }^{1}$ Department of Animal Science and Production, Botswana College of Agriculture, Private Bag 0027, Gaborone, Botswana.

${ }^{2}$ Department of Animal Science and ${ }^{3}$ Department of Plant Science, University of Wyoming, Laramie, WY 82071 , USA

*Corresponding author: ctsopito@bca.bw

\begin{abstract}
Four ruminally and duodenally cannulated mature ewes (BW $65.84 .6 \mathrm{~kg}$ ) were used in a 4 x 4 Latin square designed experiment to investigate the replacement value of alfalfa leaves (AL) for soybean meal (SBM) protein. Ewes received basal diets consisting of bromegrass hay, cracked corn, and one of four protein supplements. Diets were formulated to be isonitrogenous by replacing SBM with AL on a nitrogenous basis. Supplement treatments were: $100 \% \mathrm{SBM} ; 33.3 \% \mathrm{AL}$ and $66.7 \% \mathrm{SBM} ; 66.7 \% \mathrm{AL}$ and $33.3 \% \mathrm{SBM}$ and $100 \% \mathrm{AL}$. Experimental periods were 14 days with 10 days of diet adaptation followed by 4 days of ruminal, duodenal, and fecal sample collection. Replacing $\mathrm{SBM}$ with $\mathrm{AL}$ decreased intake of $\mathrm{OM}$ and NDF (quadratic; $P<.02$ ). Intake of $\mathrm{N}$ increased as AL replaced SBM, which resulted in a cubic effect $(P=.06)$. Organic matter flow and true ruminal OM digestibility were not affected $(P$. .18) by replacement of SBM with AL. Lower and total tract OM digestibility increased from the $33.3 \% \mathrm{AL}$ to the $66.7 \% \mathrm{AL}$ diet and decreased from the $66.7 \% \mathrm{AL}$ to the $100 \% \mathrm{AL}$ dietary treatment resulting in cubic effects $(P=.01$ and .03 , respectively). Nitrogen flow and true ruminal $\mathrm{N}$ digestibility were not influenced $(P .18)$ by supplemental protein treatment. Greater lower tract $\mathrm{N}$ digestibility for 33 and $67 \%$ AL resulted in a quadratic effect $(P=.05)$, whereas total tract $\mathrm{N}$ digestibility was not affected $(P .13)$ by replacing SBM with AL. No treatment differences $(P$ .20) were detected for NDF flow or ruminal NDF digestibility. Digestibility of NDF entering the small intestine tended to respond quadratically $(P=.09)$ with a tendency for a cubic effect $(P=.08)$ for total tract NDF digestibility as a result of greater digestibility of $66.7 \% \mathrm{AL}$ diet. Ruminal $\mathrm{pH}$ increased quadratically $(P=.0004)$, while ruminal $\mathrm{NH}_{3} \mathrm{~N}$ tended to decrease linearly $(P=.10)$ as AL replaced SBM. Ruminal particulate and fluid passage rates were not influenced $\left(\begin{array}{l}P \\ .21\end{array}\right)$ by replacing SBM with AL. Total VFA concentrations within the rumen decreased in a quadratic $(P=.05)$ fashion. Acetate:propionate ratio responded quadratically $(P=.0001)$ due to higher acetate:propionate ratios for diets containing a combination of supplementary protein. Alfalfa leaves can replace soybean meal as a protein supplement; however, greater nutritional value was apparent when the two protein sources constituted the supplement.
\end{abstract}

Key Words: Alfalfa, Protein, Replacement value, Digestion 


\section{Introduction}

Protein supplementation is a common practice in the ruminant livestock industry, particularly with ruminants fed low-quality forages. Digestion of lowquality forages by ruminants usually increases when supplemental degradable intake protein (DIP) is fed. Studies indicate that alfalfa and high-protein concentrates, when fed to provide similar amounts of $\mathrm{CP}$, elicit similar effects on forage digestion and utilization (Cochran et al., 1986; DelCurto et al., 1990a; Hannah et al., 1991).

Soybean meal (SBM) is a common source of supplemental protein for ruminants. However, the use of supplemental SBM in many areas of the United States may be limited due to low availability. Alternatively, alfalfa (Medicago sativa L.) is readily available because it is a widely grown forage crop (Barnes et al., 1988). Leaves in alfalfa hay are diluted by the stem fraction which is mainly composed of highly fibrous cell wall constituents of low CP content and high lignin content. Thus, alfalfa hay may not be comparable to SBM as a protein supplement. Results of two companion papers (Tsopito et al., 1999a,b) indicated that protein content and quality of alfalfa leaves (AL) was greater than that of alfalfa hay. The objective of this study was to investigate the replacement value of $\mathrm{AL}$ for $\mathrm{SBM}$ as a protein supplement.

\section{Materials and Methods \\ General}

Four ruminally and duodenally cannulated mature ewes (avg. initial BW $65.84 .6 \mathrm{~kg}$ ) were used in accordance with a protocol approved by the University of Wyoming Animal Care and Use Committee. Ewes were housed in a temperaturecontrolled room with continuous lighting. Sheep were placed in individual metabolism crates and

had ad libitum access to fresh water and trace mineralized salt (Trace Mineralized Salt, Akzo Salt, Inc.; guaranteed analysis [percentage of $\mathrm{DM}$ ]: $\mathrm{NaCl}$, 95 to $99 ; \mathrm{Co}, \mathrm{Cu}, \mathrm{I}, \mathrm{Mn}, \mathrm{Zn}$, and $\mathrm{Fe},<1$ ) throughout the study. Basal diets were fed at $95 \%$ of maintenance and consisted of bromegrass hay and cracked corn and one of four protein supplements. Diets were fed in equal allotments at 0700 and 1900 hours. Ewes were assigned to one of the four supplemental protein treatments according to the randomization table of Neter et al. (1990) for a 4 x 4 Latin square design experiment. Alfalfa leaves replaced supplemental protein from SBM to provide supplemental protein treatments of: $100 \%$ SBM; $33.3 \%$ AL plus $66.7 \%$ SBM; $66.7 \%$ AL plus $33.3 \% \mathrm{SBM}$; and $100 \% \mathrm{AL}$. Alfalfa leaves replaced increasing amounts of SBM and bromegrass hay to ensure isonitrogenous diets (Table 1).

Sampling

As an indigestible marker of digesta flow, $\mathrm{Cr}_{2} \mathrm{O}_{3}(2.5$ g) was delivered intraruminally at each feeding. Experimental periods were 14 days with 10 days of diet adaptation and 4 days of sample collection. Representative samples of each feed ingredient were collected at each feeding, composited within each experimental period, and stored for analysis.

Beginning at 0500 hours on day 1 of each sampling period, duodenal and fresh fecal grab samples were collected at 4-hour intervals. Collection times were advanced 6 hours on day 2 of sampling to obtain samples that represented every 2 hours of a 24 -hour period. Duodenal and fecal samples, respectively, were composited on an equal volume basis for each ewe within each sampling period. 
Table 1. Ingredients and chemical composition of the diets fed to mature ewes

Treatment ${ }^{\mathrm{a}}$

Item

$100 \%$ SBM $\quad 33.3 \%$ AL $\quad 66.7 \%$ AL $\quad 100 \%$ AL

Ingredients, \%

Bromegrass hay

61.1

55.5

48.3

39.1

Cracked corn

25.2

25.2

25.1

25.2

Soybean meal

13.8

10.0

5.1

Alfalfa leaves

9.3

21.1

35.6

Chemical composition

DM, \%

95.2

95.1

94.8

95.1

$\mathrm{OM}, \%$ of DM

\begin{tabular}{llll}
88.2 & 88.0 & 87.8 & 87.5 \\
\hline 20.0 & 20.1 & 20.4 & 20.9 \\
58.7 & 57.4 & 55.5 & 53.0 \\
30.5 & 30.1 & 29.2 & 28.2
\end{tabular}

ADF

CP

${ }^{\mathrm{a}}$ Treatment: supplemental protein $=100 \%$ soybean meal $(\mathrm{SBM})$, supplemental protein $=33.3 \%$ alfalfa leaves (AL)

30.1

28.2 and $66.7 \% \mathrm{SBM}$, supplemental protein $=66.7 \% \mathrm{AL}$ and $33.3 \% \mathrm{SBM}$, and supplemental protein $=100 \% \mathrm{AL}$.

Duodenal samples were stored at $-20 \mathrm{C}$. Fecal samples were refrigerated $(4 \mathrm{C})$ until the end of the collection period and then dried in a forced-air oven at $55 \mathrm{C}$.

On day 2 of each sampling period, approximately $100 \mathrm{~mL}$ of whole ruminal contents were collected from each ewe immediately before feeding at 0700 (0-h sampling time). Ruminal contents were strained through four layers of cheesecloth and $\mathrm{pH}$ measured immediately. Strained samples were acidified with $0.1 \mathrm{~mL}$ of $7.2 \mathrm{~N} \mathrm{H}_{2} \mathrm{SO}_{4} / 10 \mathrm{~mL}$ ruminal fluid, and frozen $(-20 \mathrm{C})$. The resulting boluses from strained ruminal contents were dried in a forced-air oven ( $55 \mathrm{C}$ for $48 \mathrm{~h}$ ) and ground in a Wiley mill to pass a 2-mm screen. The remainder of ruminal contents (unstrained) were then placed into $3.8 \mathrm{~L}$ plastic jugs containing saline solution $\left(9 \mathrm{~g} \mathrm{NaCl} / 1 \mathrm{~L} \mathrm{H}_{2} \mathrm{O}\right)$ and stored at $-20 \mathrm{C}$ for isolation of ruminal bacteria. Following initial collection of ruminal contents, each ewe was dosed intraruminally with wetted $50 \mathrm{~g}$ Yb-labeled bromegrass hay (Teeter et al., 1984) and $50 \mathrm{~mL}$ of CoEDTA (Uden et al., 1980) for determination of particulate and fluid passage rates, respectively. Additional ruminal samples were taken at 4, 8, 12, 16, and $20 \mathrm{~h}$ after feeding and processed in the same manner as the 0 - $\mathrm{h}$ sample.
Sample Processing
Duodenal samples were freeze-dried (Model 10- MR-TR Freeze Dryer, Virtis Co., NY). Feed composites, and dried duodenal and fecal samples were ground to pass a $1 \mathrm{~mm}$ 
screen using a Wiley mill. Frozen ruminal contents were thawed, saline $\left(9 \mathrm{~g} \mathrm{NaCl} / \mathrm{L} \mathrm{H}_{2} \mathrm{O}\right)$ added and homogenized in a blender (Hamilton Beach/ProctorSilex, Inc., Model 702R, Washington, NC) to release particulate-associated microbes from feed particles (Firkins et al., 1986). The mixture was strained through four layers of cheesecloth and the resulting fluid fraction was separated from the particulate fraction via centrifugation at $1,000 \mathrm{x} g$ for $10 \mathrm{~min}$. The supernantant was retained and re-centrifuged at $10,000 \times g$ for $30 \mathrm{~min}$. Following rinsing with saline (2 parts saline: 1 part pellet) and recentrifugation $(10,000$ $\mathrm{x} g$ for $30 \mathrm{~min}$ ), the resulting bacteria-rich pellet was isolated and stored in saline $\left(9 \mathrm{~g} \mathrm{NaCl} / \mathrm{L} \mathrm{H}_{2} \mathrm{O}\right)$ on an equal volume basis for later analysis.

Acidified ruminal samples were thawed at room temperature and centrifuged at $10,000 \times \mathrm{g}$ for $10 \mathrm{~min}$. The resulting supernatant was collected for VFA, Co, and $\mathrm{NH}_{3} \mathrm{~N}$ concentration determination. To $2.5 \mathrm{~mL}$ of centrifuged ruminal fluid, $.5 \mathrm{~mL}$ of $25 \%$ (wt/vol) metaphosphoric acid containing $2 \mathrm{~g} / \mathrm{L} 2$-ethylbutyrate (2-EB) were added, and the mixture centrifuged at $10,000 \times g$ for $10 \mathrm{~min}$. The supernatants were transferred into glass vials $(2.2 \mathrm{~mL})$, capped and stored (4 C).

\section{Laboratory Analyses}

Ground composites of feed, duodenal, and fecal samples were analyzed for DM, ash, Kjeldahl N (AOAC, 1990), ADF and NDF (Goering and Van Soest, 1970). Isolated ruminal bacteria were analyzed for purines (Zinn and Owens, 1986), DM, ash, and Kjeldahl N (AOAC, 1990). Chromium was extracted by perchloric acid from ground duodenal and fecal samples, and $\mathrm{Cr}$ concentrations determined by atomic absorption spectroscopy (Model 210 VDT AASpectr., E. Norwalk, CT) with an air- acetylene flame (Hill and Anderson, 1958; Williams et al., 1962). Ytterbium was extracted from ground ruminal boluses with $.05 \mathrm{M}$ EDTA containing $3.8 \mathrm{~g}$ of $\mathrm{KCl} / \mathrm{L}$ as an ionization buffer (Teeter et al., 1984). Ytterbium concentrations were measured by atomic absorption spectroscopy with an air-acetylene and nitrous oxide flame (Hart and Polan, 1984). Ruminal fluid supernatant was analyzed for Co concentration by atomic absorption spectroscopy with an airacetylene flame, $\mathrm{NH}_{3} \mathrm{~N}$ by the phenol-hypochlorite assay (Broderick and Kang, 1980). Volatile fatty acid concentrations were determined by gas chromatography (Goetsch and Galyean, 1983; Whitney 1998) using a Hewlett Packard 5890 Series II GC equipped with a $15 \mathrm{~m} \times .53 \mathrm{~mm}$ (i. d.) column (Nukol; Supelco, Bellefonte, PA) with oven temperature ramp of $110 \mathrm{C}$ to $150 \mathrm{C}$ at $8 \mathrm{C}$ per min, and Helium as carrier gas $(20 \mathrm{~mL} / \mathrm{min})$. Injector and detector temperatures were $250 \mathrm{C}$.

\section{Calculations}

Nutrient flows at the duodenum as well as fecal output were calculated by reference to Cr. Apparent ruminal, lower tract, and total tract digestion of nutrients were calculated as the difference between nutrient intake, duodenal flow, and fecal excretion of nutrients, respectively. The purine: $\mathrm{N}$ ratio of isolated ruminal bacteria was used in conjunction with the duodenal purine content to calculate microbial $\mathrm{N}$ flow to the duodenum. True ruminal $\mathrm{OM}$ and $\mathrm{N}$ digestibilities were determined by correcting apparent ruminal digestibilities for microbial $\mathrm{OM}$ and $\mathrm{N}$ flow to the duodenum. Bacterial protein synthesis was expressed as grams of microbial N per kilogram of OM truly fermented in the rumen.

Ruminal fluid and particulate passage rates were calculated by regressing the natural logarithm of $\mathrm{Yb}$ and Co concentration 
South .Afr. J. Educ. Sci. Technol.2(2) (2007)

against sampling time after dosing (Uden et al., 1980). Volatile fatty acids areas were adjusted for detector responses with a set of correction factors developed to determine the $\mathrm{mg} / \mathrm{g}$ values and mmol values calculated from these values using formula weights for each VFA molecule.

\section{Statistical Analyses}

Data were analyzed by ANOVA using GLM procedure of SAS (1989). Intakes, fluid and particulate passage rates, digesta flows, and digestibilities were analyzed by ANOVA in a $4 \times 4$ Latin square design. Ruminal $\mathrm{pH}, \mathrm{NH}_{3} \mathrm{~N}$, and VFA data were analyzed as a split-plot to examine the effects of time. Treatment $x$ sampling time interactions were not detected $(P>.10)$; therefore, treatment sums of squares for all data were partitioned into linear, quadratic, and cubic effects of $\mathrm{AL}$ replacement. One ewe died on day 4 of the third experimental period due to unknown causes. Hence, treatment means were calculated using the LSMEANS option of SAS (1989).

\section{Results and Discussion}

Intakes

Although intakes were controlled at $95 \%$ of maintenance requirements, $\mathrm{OM}$ intake decreased quadratically $(P=.02)$ and $\mathrm{N}$ intake increased linearly $(P=.0001)$ as $\mathrm{AL}$ replaced supplemental SBM (Table 2 and 3). The response noted for OM intake corresponded with lower levels of $\mathrm{OM}$ in $\mathrm{AL}$ (Table 1). Due to the lower CP content of $\mathrm{AL}$ compared to SBM, AL also replaced bromegrass hay as AL dietary percentage increased. Therefore, NDF intake decreased quadratically $(P=.0003)$ as $\mathrm{AL}$ replaced supplemental SBM(Table 4). 
Table 2. Intake, flow and digestibility of organic matter by mature ewes fedalfalfa leaves as a replacement for soybean meaprotein

\begin{tabular}{|c|c|c|c|c|c|c|c|}
\hline \multirow[b]{2}{*}{ Item } & \multicolumn{4}{|c|}{ Treatment $^{\mathrm{a}}$} & \multicolumn{3}{|c|}{ Contrast $^{\mathrm{b}}$} \\
\hline & $\overline{100 \% \mathrm{SBM}}$ & $33.3 \% \mathrm{AL}$ & $66.7 \% \mathrm{AL}$ & $100 \% \mathrm{AL}$ & Linear & Quadratic & Cubic \\
\hline OM intake, $\mathrm{g} / \mathrm{d}$ & $1048.9 \pm .8$ & $1046.7 \pm .6$ & $1044.4 \pm .6$ & $1037.1 \pm .8$ & .0003 & .02 & .13 \\
\hline Total duodenal OM & & & & & & & \\
\hline $\begin{array}{l}\text { flow, g/d } \\
32.0\end{array}$ & $\begin{array}{c}642.8 \pm 32.0 \\
.43\end{array}$ & $\begin{array}{c}647.9 \pm 24.2 \\
.40\end{array}$ & $\begin{array}{c}654.6 \pm 24.2 \\
.61\end{array}$ & $602.3 \pm$ & & & \\
\hline Microbial OM flow, g/d & $223.7 \pm 11.3$ & $224.2 \pm 8.5$ & $214.6 \pm 8.5$ & $202.4 \pm 11.3$ & .18 & .57 & .86 \\
\hline $\begin{array}{l}\text { Apparent ruminal OM } \\
\text { digestion, } \mathrm{g} / \mathrm{d}\end{array}$ & $406.0 \pm 32.6$ & $398.9 \pm 24.6$ & $389.9 \pm 24.6$ & $434.8 \pm 32.6$ & .60 & .44 & .65 \\
\hline Apparent ruminal OM & & & & & & & \\
\hline digestibility, $\%$ of intake & $38.7 \pm 3.1$ & $38.1 \pm 2.4$ & $37.3 \pm 2.4$ & $41.9 \pm 3.1$ & .60 & .41 & .53 \\
\hline $\begin{array}{l}\text { OM truly fermented, } \mathrm{g} / \mathrm{d} \\
\text { True ruminal OM }\end{array}$ & $629.7 \pm 39.9$ & $623.0 \pm 30.2$ & $604.5 \pm 30.2$ & $637.1 \pm 39.9$ & .98 & .62 & .67 \\
\hline digestibility, $\%$ of intake & $60.0 \pm 3.9$ & $59.5 \pm 2.9$ & $57.8 \pm 2.9$ & $61.4 \pm 3.9$ & .91 & .61 & .60 \\
\hline $\begin{array}{l}\text { Fecal OM output, } \mathrm{g} / \mathrm{d} \\
\text { Lower tract OM }\end{array}$ & $274.4 \pm 11.4$ & $276.8 \pm 8.6$ & $236.7 \pm 8.6$ & $265.6 \pm 11.4$ & .22 & $.72^{\circ}$ & .27 \\
\hline $\begin{array}{l}\text { digestion, g/d } \\
\text { Lower tract OM }\end{array}$ & $368.5 \pm 24.7$ & $371.1 \pm 18.6$ & $417.9 \pm 18.6$ & $336.7 \pm 24.7$ & .65 & .14 & .11 \\
\hline $\begin{array}{l}\text { digestibility, } \% \text { entering } \\
\text { Total tract } \mathrm{OM}\end{array}$ & $57.3 \pm 1.3$ & $57.3 \pm 1.0$ & $63.8 \pm 1.0$ & $55.9 \pm 1.3$ & .80 & .05 & .01 \\
\hline $\begin{array}{l}\text { digestion, } \mathrm{g} / \mathrm{d} \\
\text { Total tract } \mathrm{OM}\end{array}$ & $774.5 \pm 11.8$ & $769.9 \pm 8.9$ & $807.8 \pm 8.9$ & $771.5 \pm 11.8$ & .58 & .22 & .05 \\
\hline digestibility, $\%$ of intake & $73.8 \pm .9$ & $73.5 \pm .7$ & $77.4 \pm .7$ & $74.4 \pm .9$ & .25 & .25 & .03 \\
\hline
\end{tabular}

${ }^{\mathrm{a}}$ Treatment: supplemental protein $=100 \%$ soybean meal $(\mathrm{SBM})$, supplemental meal $=33.3 \%$ alfalfa leaves $(\mathrm{AL})$ and $66.7 \%$

$\mathrm{SBM}$, supplemental protein $=66.7 \% \mathrm{AL}$ and $33.3 \% \mathrm{SBM}$, and supplemental protein $=100 \% \mathrm{AL}$.

${ }^{b}$ Observed $P$-values for polynomial contrasts. 
Table 3. Intake, flow and digestion of nitrogen by mature ewes fed alfalfa leaves as a replacement for soybean meal protein

\begin{tabular}{|c|c|c|c|c|c|c|c|}
\hline \multirow[b]{2}{*}{ Item } & \multicolumn{4}{|c|}{ Treatmenta } & \multicolumn{3}{|c|}{ Contrastb } \\
\hline & $100 \% \mathrm{SBM}$ & $33.3 \% \mathrm{AL}$ & $66.7 \% \mathrm{AL}$ & $100 \% \mathrm{AL}$ & Linear & Quadratic & Cubic \\
\hline $\mathrm{N}$ intake, $\mathrm{g} / \mathrm{d}$ & $33.6 \pm .04$ & $33.7 \pm .03$ & $34.1 \pm .03$ & $34.6 \pm .04$ & .0001 & .01 & .06 \\
\hline Total duodenal N flow, g/d & $20.8 \pm 2.2$ & $24.1 \pm 1.7$ & $23.8 \pm 1.7$ & $21.7 \pm 2.2$ & .81 & .26 & .85 \\
\hline Duodenal $\mathrm{NH}_{3} \mathrm{~N}, \mathrm{~g} / \mathrm{d}$ & $2.3 \pm .8$ & $3.1 \pm .6$ & $4.0 \pm .6$ & $2.4 \pm .6$ & .70 & .18 & .36 \\
\hline Feed N flow, g/d & $6.9 \pm 2.1$ & $9.2 \pm 1.6$ & $8.3 \pm 1.6$ & $6.9 \pm 2.1$ & .93 & .38 & .74 \\
\hline $\begin{array}{l}\text { Microbial N flow, } \mathrm{g} / \mathrm{d} \\
\text { Microbial efficiency, } \\
\text { g microbial N flow } / \mathrm{kg} \text { OM }\end{array}$ & $11.7 \pm: 6$ & $11.8 \pm .4$ & $11.5 \pm .4$ & $12.4 \pm .6$ & .49 & .53 & .40 \\
\hline $\begin{array}{l}\text { truly fermented } \\
\text { Apparent ruminal N }\end{array}$ & $18.4 \pm .9$ & $19.2 \pm .7$ & $20.0 \pm .7$ & $19.7 \pm .9$ & .24 & .56 & .74 \\
\hline $\begin{array}{l}\text { digestion, } \mathrm{g} / \mathrm{d} \\
\text { Apparent ruminal } \mathrm{N}\end{array}$ & $12.8 \pm 2.3$ & $9.6 \pm 1.8$ & $10.3 \pm 1.8$ & $12.7 \pm 2.3$ & .81 & .34 & .71 \\
\hline $\begin{array}{l}\text { digestibility, } \% \text { of intake } \\
\text { True ruminal } \mathrm{N}\end{array}$ & $38.1 \pm 6.7$ & $28.5 \pm 5.1$ & $30.2 \pm 5.1$ & $36.8 \pm 6.7$ & .71 & .33 & .83 \\
\hline digestibility, $\%$ of intake & $60.6 \pm 3.6$ & $63.5 \pm 2.7$ & $62.6 \pm 2.7$ & $62.2 \pm 3.6$ & .91 & .71 & .92 \\
\hline Fecal $N$ output, g/d & $5.9 \pm .3$ & $5.7 \pm .2$ & $4.9 \pm .2$ & $6.0 \pm .3$ & .64 & .07 & .09 \\
\hline $\begin{array}{l}\text { Lower tract } \mathrm{N} \text { digestion, } \mathrm{g} / \mathrm{d} \\
\text { Lower tract } \mathrm{N} \text { digestibility, }\end{array}$ & $14.9 \pm 2.2$ & $18.4 \pm 1.6$ & $18.9 \pm 1.6$ & $15.9 \pm 2.2$ & .75 & .17 & .93 \\
\hline$\%$ of intake & $44.4 \pm 6.4$ & $54.6 \pm 4.8$ & $55.4 \pm 4.8$ & $46.0 \pm 6.4$ & .50 & .05 & .18 \\
\hline $\begin{array}{l}\text { Total tract } \mathrm{N} \text { digestion, } \mathrm{g} / \mathrm{d} \\
\text { Total tract } \mathrm{N} \text { digestibility, }\end{array}$ & $27.7 \pm .34$ & $28.0 \pm .26$ & $29.2 \pm .26$ & $28.6 \pm .34$ & .15 & .08 & .05 \\
\hline$\%$ of intake & $82.5 \pm 1.1$ & $83.1 \pm .8$ & $85.6 \pm .8$ & $82.7 \pm 1.1$ & .95 & .13 & .84 \\
\hline
\end{tabular}

$\mathrm{SBM}$, supplemental protein $=66.7 \% \mathrm{AL}$ and $33.3 \% \mathrm{SBM}$, and supplemental protein $=100 \% \mathrm{AL}$.

bObserved $P$-values for polynomial contrasts. 
Table 4. Intake, flow and digestibility of neutral detergent fiber by mature ewes fed alfalfa leaves as a replacement for soybean meal protein

\begin{tabular}{|c|c|c|c|c|c|c|c|}
\hline \multirow[b]{2}{*}{ Item } & \multicolumn{4}{|c|}{ Treatmenta } & \multicolumn{3}{|c|}{ Contrastb } \\
\hline & $100 \% \mathrm{SBM}$ & $33.3 \% \mathrm{AL}$ & $66.7 \% \mathrm{AL}$ & $100 \% \mathrm{AL}$ & Linear & Quadratic & Cubic \\
\hline NDF intake, $\mathrm{g} / \mathrm{d}$ & $614.3 \pm 1.7$ & $600.3 \pm 1.0$ & $579.3 \pm 1.0$ & $549.7 \pm 1.7$ & .0001 & .003 & .73 \\
\hline $\begin{array}{l}\text { Total duodenal NDF flow, } \\
\text { g/d }\end{array}$ & $264.9 \pm 19.5$ & $290.0 \pm 14.7$ & $260.4 \pm 14.7$ & $244.9 \pm 19.5$ & .32 & .32 & .37 \\
\hline $\begin{array}{l}\text { Apparent ruminal NDF } \\
\text { digestion, g/d } \\
\text { Apparent ruminal NDF }\end{array}$ & $349.3 \pm 19.8$ & $310.8 \pm 15.0$ & $319.2 \pm 15.0$ & $305.1 \pm 19.8$ & .20 & .54 & .37 \\
\hline digestibility, $\%$ of intake & $56.8 \pm 3.3$ & $51.8 \pm 2.5$ & $55.1 \pm 2.5$ & $55.5 \pm 3.3$ & .94 & .43 & .42 \\
\hline $\begin{array}{l}\text { Fecal NDF output, } g / \mathrm{d} \\
\text { Lower tract NDF digestion, }\end{array}$ & $185.9 \pm 11.5$ & $183.3 \pm 8.7$ & $149.9 \pm 8.7$ & $170.0 \pm 11.5$ & .15 & .35 & .10 \\
\hline $\begin{array}{l}\text { Lower tract NDF digestion, } \\
\text { g/d } \\
\text { Lower tract NDF }\end{array}$ & $79.0 \pm 16.6$ & $106.7 \pm 12.6$ & $110.4 \pm 12.6$ & $74.9 \pm 16.6$ & .91 & .11 & .80 \\
\hline $\begin{array}{l}\text { digestibility, \% entering } \\
\text { Total tract NDF digestion, }\end{array}$ & $29.8 \pm 4.1$ & $36.8 \pm 3.1$ & $42.4 \pm 3.1$ & $30.6 \pm 4.1$ & .85 & .09 & .21 \\
\hline $\begin{array}{l}\text { Total tract NDF digestion, } \\
\text { g/d } \\
\text { Total tract NDF }\end{array}$ & $428.3 \pm 10.7$ & $417.5 \pm 8.1$ & $429.6 \pm 8.1$ & $380.0 \pm 10.7$ & .04 & .12 & .08 \\
\hline $\begin{array}{l}\text { Total tract NDF } \\
\text { digestibility, } \% \text { of intake }\end{array}$ & $69.7 \pm 1.8$ & $69.6 \pm 1.4$ & $74.2 \pm 1.4$ & $69.1 \pm 1.8$ & .93 & .21 & .08 \\
\hline
\end{tabular}

\begin{tabular}{llllllll} 
digestibility, $\%$ of intake & $69.7 \pm 1.8$ & $69.6 \pm 1.4$ & $74.2 \pm 1.4$ & $69.1 \pm 1.8$ & .93 & .21 & .08 \\
\hline aTreatment: supplemental protein $=100 \%$ soybean meal (SBM), supplemental prote in $=33.3 \%$ alfalfa leaves (AL) and $66.7 \%$
\end{tabular}

$\mathrm{SBM}, \quad$ supplemental protein $=66.7 \% \mathrm{AL}$ and $33.3 \% \mathrm{SBM}$, and supplemental $=100 \% \mathrm{AL}$.

bObserved $P$-values for polynomial contrasts. 


\section{Organic Matter Digestion}

An increase from $33.3 \% \mathrm{AL}$ to $66.7 \% \mathrm{AL}$ and a decrease from $66.7 \% \mathrm{AL}$ to $100 \% \mathrm{AL}$ caused quadratic and cubic effects $(P=.05$ and .01 , respectively) for lower tract $\mathrm{OM}$ digestibility while causing cubic $(P=.03)$ effects for total tract OM digestibility as SBM was replaced with AL. Galyean and Owens (1991) suggested that source of supplemental $\mathrm{N}$ generally seemed unimportant in altering site of OM digestion. Results of this study were similar to those of Stafford et al. (1996) who observed increased total tract OM digestibility when supplementing tallgrass-prairie forage with highquality alfalfa hay $(17.5 \% \mathrm{CP})$. However, Stafford et al. (1996) noted decreased total tract OM digestibility with supplemental pelleted alfalfa dehy $(17.5 \% \mathrm{CP})$ compared to higher CP soybean meal-based supplements. Alfalfa leaves are normally of higher quality than alfalfa hay. Therefore, $\mathrm{AL}$ is a likely replacement for supplemental SBM.

\section{Nitrogen Digestion}

An increase from $100 \% \mathrm{SBM}$ to $66.7 \% \mathrm{AL}$ and a decrease from $66.7 \% \mathrm{AL}$ to $100 \% \mathrm{AL}$ induced a quadratic $(P=.05)$ effect for lower tract $\mathrm{N}$ digestibility. Cotta and Hespell (1986) noted that the amount of $\mathrm{N}$ apparently digested in the small intestine was a good indication of the protein available to the host animal. Therefore, 33.3 and $66.7 \% \mathrm{AL}$ treatments provided greater metabolizable protein than each protein source fed alone.

\section{Neutral Detergent Fiber Digestion}

Digestibility of NDF in the lower tract tended to increase from $100 \% \mathrm{SBM}$ to $66.7 \% \mathrm{AL}$, and to decrease from $66.7 \%$ AL to $100 \%$ AL causing a quadratic $(P=.09)$ effect as supplemental SBM was replaced with AL; similar fluctuations also induced a cubic $(P=.08)$ effect on total tract NDF digestibility. Stefanon et al. (1996) showed that alfalfa hay had less structural fiber than bromegrass hay, but this fiber appeared to contain a relatively slower digesting component. A portion of this slower digesting fiber component of the AL treatments may have escaped ruminal digestion, then was digested in the lower tract. Greater lower tract NDF digestibility may not have occurred for the $100 \%$ AL treatment because of the greater proportion of fiber from bromegrass hay reaching the lower tract for this treatment. Particulate passage rate for the $100 \% \mathrm{AL}$ treatment was $10 \%$ greater than that of the other treatments suggesting greater duodenal flow of bromegrass hay because bromegrass hay was labeled with $\mathrm{Yb}$ for this experiment.

\section{Ruminal pH, Ammonia, and Passage Rates}

Replacing supplemental SBM with AL increased ruminal $\mathrm{pH}$ from the $100 \% \mathrm{SBM}$ to the $33.3 \% \mathrm{AL}$ diet and decreased $\mathrm{pH}$ from the $33.3 \% \mathrm{AL}$ to the $100 \% \mathrm{AL}$ diet such that linear $(P=.03)$ and quadratic $(P=$ .0004) effects occurred (Table 5). Ruminal $\mathrm{NH}_{3} \mathrm{~N}$ concentration tended to decrease linearly $(P=.10)$ as AL replaced supplemental SBM (Table 5). Broderick et al. (1993) observed a similar trend in lactating cows fed SBM, unprocessed and processed alfalfa hay. Erdman et al. (1986) indicated that the concentration of ruminal $\mathrm{NH}_{3} \mathrm{~N}$ needed for maximum digestion is a function of the fermentability of the diet. Although OM truly fermented in the rumen was not statistically different across treatments, it was worth noting numerical differences of OM truly fermented that may have a biological effect on some ruminal fermentation parameters such as ruminal $\mathrm{NH}_{3} \mathrm{~N}$ concentrations. 
Decreased ruminal $\mathrm{NH}_{3} \mathrm{~N}$ concentrations for the $100 \%$ AL diet may also have been due to the quality of protein presented to ruminal microbes for degradation. Van Soest (1994) noted that leaf proteins were of higher quality than storage proteins found in plant seeds (SBM) because of their extent of solubility. Storage proteins tend to be rapidly soluble compared with leaf proteins that contain extensin proteins of the plant cell wall. The extensin proteins account for a small portion in the leaves, but tend to reduce rapid degradability of the leaves (Van Soest, 1994). Thus, soybean meal proteins (which are storage proteins) tend to be more rapidly degraded in the rumen, producing higher levels of ruminal $\mathrm{NH}_{3} \mathrm{~N}$. Nonetheless, ruminal $\mathrm{NH}_{3} \mathrm{~N}$ concentrations observed in this study were within the 2.2 to $23.5 \mathrm{mg} / \mathrm{dL}$ range suggested by Clark and Davis (1983) to be optimal for $\mathrm{OM}$ digestion. Moreover, $\mathrm{NH}_{3} \mathrm{~N}$ concentrations were above the 3.3 to $8.5 \mathrm{mg} / \mathrm{dL}$ range considered optimal for ruminal fermentation (Kang-Meznarich and Broderick, 1981), and above the $6.2 \mathrm{mg} / \mathrm{dL}$ required when dietary CP is over 6\% (Hoover, 1986).

\section{Ruminal Volatile Fatty Acids}

Total ruminal VFA concentrations (Table 6) decreased from the $100 \%$ SBM to the $66.7 \%$ AL diet, then increased from the $66.7 \% \mathrm{AL}$ to the $100 \% \mathrm{AL}$ diet resulting in a quadratic $(P=.05)$ effect which was similar to the trends noted for OM truly fermented in the rumen. However, trends for ruminal $\mathrm{pH}$ resembled those of total ruminal VFA concentrations. Higher total VFA concentrations are known to lower ruminal pH (Stokes et al., 1988; DelCurto et al., 1990b; Sunvold et al., 1991).

Ruminal molar proportions of acetate were influenced (quadratic, cubic and linear; $P=.0003$, .02 , and .07 , respectively) as supplemental SBM was replaced by $\mathrm{AL}$.
Dietary treatment effects (quadratic and cubic; $P=$ .0001 and .01 , respectively) were detected for ruminal molar proportions of propionate as $\mathrm{AL}$ replaced supplemental SBM. Ruminal acetate:propionate $(\mathrm{A}: \mathrm{P})$ ratio had a quadratic $(P=$ $.0001)$ and cubic $(P=.003)$ response due to greater A:P ratios for the 33.3 and $66.7 \%$ AL treatments. The A:P ratio is an indicator of the metabolic pathway used by ruminal bacteria in converting monosaccharides to VFA (Stefanon et al., 1996). Changes in the A:P ratio associated with the various diets may also be due to the fiber component being degraded differently within the rumen. Greater A: P ratios for the 33.3 and $67.7 \% \mathrm{AL}$ treatments indicate the predominance of acetate producing bacteria. Conversely, lower A:P ratios for the $100 \%$ SBM and $100 \% \mathrm{AL}$ diets indicate a bacterial species predominately synthesizing propionate. Ruminal $\mathrm{pH}$ for these treatments ( $\mathrm{pH}$ 5.9) also was supportive of changes in ruminal A:P ratios. Ruminal $\mathrm{pH}$ less than 6.0 restricts the activity of cellulolytic bacteria (Orskov,1992), which are responsible for acetate synthesis.

Ruminal molar proportions of butyrate were influenced linearly $(P=.02)$, quadratically $(P=.05)$, and cubically $(P=.01)$. Butyrate increased when the diet was changed from $100 \% \mathrm{SBM}$ to $33.3 \% \mathrm{AL}$, and then decreased when the diet was changed from $33.3 \% \mathrm{AL}$ to $100 \% \mathrm{AL}$. The higher ruminal molar proportions of butyrate for the $33.3 \% \mathrm{AL}$ treatment compared to other dietary treatments induced the quadratic response since if this treatment was not considered, the response would have been a linear decrease in butyrate concentrations as replaced SBM. Increased digestion of NSC in SBM (Schadt et al., 1999) may have contributed to the response noted for ruminal molar proportions of butyrate. Additionally, the relatively high ruminal molar 
Table 5. Ruminal $\mathrm{pH}$, ammonia and passage rate mature ewes fed alfalfa leaves as a replacement for soybean meal protein

\begin{tabular}{|c|c|c|c|c|c|c|c|}
\hline \multirow[b]{2}{*}{ Item } & \multicolumn{4}{|c|}{ Treatmenta } & \multicolumn{3}{|c|}{ Contrastb } \\
\hline & $100 \% \mathrm{SBM}$ & $33.3 \% \mathrm{AL}$ & $66.7 \% \mathrm{AL}$ & $100 \% \mathrm{AL}$ & Linear & Quadratic & Cubic \\
\hline $\mathrm{pH}$ & $5.7 \pm .07$ & $6.1 \pm .06$ & $6.0 \pm .06$ & $5.9 \pm .07$ & .03 & .0004 & .10 \\
\hline $\mathrm{NH}_{3} \mathrm{~N}, \mathrm{mg} / \mathrm{dL}$ & $16.3 \pm 1.2$ & $14.7 \pm 0.9$ & $14.8 \pm 0.9$ & $13.6 \pm 1.2$ & .10 & .90 & .47 \\
\hline Particulate passage rate, $\% / \mathrm{h}$ & $4.1 \pm 0.3$ & $3.9 \pm 0.2$ & $4.1 \pm 0.2$ & $4.5 \pm 0.3$ & .55 & .30 & .21 \\
\hline Fluid passage rate, $\% / \mathrm{h}$ & $6.2 \pm 0.9$ & $6.1 \pm 0.7$ & $5.4 \pm 0.7$ & $7.4 \pm 0.9$ & .50 & .30 & .34 \\
\hline
\end{tabular}

Table 6. Ruminal v olatile fatty acids of mature ewes fed alfalfa leaves as a replacement for soybean meal protein

\begin{tabular}{|c|c|c|c|c|c|c|c|}
\hline \multirow[b]{2}{*}{ Item } & \multicolumn{4}{|c|}{ Treatmenta } & \multicolumn{3}{|c|}{ Contrasth } \\
\hline & $100 \%$ SBM & $33.3 \% \mathrm{AL}$ & $66.7 \% \mathrm{AL}$ & $100 \% \mathrm{AL}$ & Linear & Quadratic & Cubic \\
\hline Total VFA, $\mathrm{m} M$ & $108.6 \pm 4.7$ & $102.2 \pm 3.5$ & $98.6 \pm 3.5$ & $109.7 \pm 4.7$ & .99 & .05 & .47 \\
\hline Acetate & $61.5 \pm .4$ & $63.9 \pm .3$ & $63.2 \pm .3$ & $62.7 \pm .4$ & .07 & .0003 & .02 \\
\hline Propionate & $21.5 \pm .6$ & $18.2 \pm .5$ & $20.0 \pm .5$ & $21.4 \pm .6$ & .55 & .000 .1 & .01 \\
\hline Acetate:Propionate & $2.9 \pm .1$ & $3.6 \pm .1$ & $3.2 \pm .1$ & $3.0 \pm .1$ & .68 & .0001 & .003 \\
\hline Butyrate & $13.0 \pm .4$ & $14.2 \pm .3$ & $12.6 \pm .3$ & $12.2 \pm .4$ & .02 & .05 & .01 \\
\hline Isobutyrate & $.9 \pm .2$ & $.9 \pm .1$ & $.9 \pm .1$ & $.7 \pm .2$ & .57 & .66 & .79 \\
\hline Valerate & $1.3 \pm .1$ & $1.3 \pm .1$ & $1.6 \pm .1$ & $1.5 \pm .1$ & .0003 & .32 & .001 \\
\hline Isovalerate & $1.8 \pm .7$ & $1.7 \pm .1$ & $1.8 \pm .1$ & $1.5 \pm .7$ & .002 & .15 & .002 \\
\hline
\end{tabular}

aTreatment: supplemental protein $=100 \%$ soybean meal $(\mathrm{SBM})$, supplemental protein $=33.3 \%$ alfalfa leaves $(\mathrm{AL})$ and $66.7 \%$

$\mathrm{SBM}$, supplemental protein $=66.7 \% \mathrm{AL}$ and $33.3 \% \mathrm{SBM}$, and supplemental protein $=100 \% \mathrm{AL}$.

${ }^{b}$ Observed $P$-values for polynomial contrasts. 
proportions of butyrate reported in the present study may have been due to inclusion of cracked corn in the basal diets of the ewes to synchronize energy with $\mathrm{N}$ provided by dietary treatments. Ruminal molar proportions of butyrate have been shown to increase with increasing starch intake (Stern et al., 1978; Grisby et al., 1991; Hess et al., 1996).

Ruminal molar proportions of valerate increased when dietary AL was increased from $33.3 \%$ to $66.7 \%$ and then decreased when dietary AL was increased from $66.7 \%$ to $100 \%$ (cubic effect, $P=.001$ ) and a decrease from $66.7 \% \mathrm{AL}$ to $100 \% \mathrm{AL}$. Increasing dietary AL from $33.3 \%$ to $100 \%$ resulted in a positive cubic $(P=.002)$ response in ruminal molar proportions of isovalerate. These minor ruminal VFA responses were considered unimportant (Gorosito et al., 1985; Gunter et al., 1990) in terms of enhanced ruminal digestion.

\section{Conclusions}

Alfalfa leaves can replace soybean meal as a protein supplement; however, greater nutritional value was apparent when the two protein sources constituted the supplement. Lower and total tract digestion of OM, N and NDF were all greater for diets containing a combination of supplemental alfalfa leaves and soybean meal, suggesting complementary effects of combining alfalfa leaf and soybean meal protein. Although alfalfa leaves can be used to replace SBM as a protein supplement, the availability, separation process, and cost of AL will determine the benefits of replacing traditional protein sources such as SBM.

\section{References}

AOAC, 1990. Official Methods of Analysis. (15th ed.). Association of Official Analytical Chemists, Arlington, VA.

Barnes, D. K.., B. P. Goplen, and J. E. Baylor. 1988. Alfalfa and alfalfa improvement, Agronomy Monograph no. 29. ASA-CSSA-SSSA
Broderick, G. A,. and J. H. Kang. 1980. Automated simultaneous determinations of ammonia and total amino acids in ruminal fluid and in vitro media. Journal of Dairy Science 63:6475 .

Broderick, G. A., J. H. Yang, and R. G. Koegel. 1993. Effect of steam heating alfalfa hay on utilization by lactating dairy cows. Journal of Dairy Science 76:165-174.

Clark, J. H., and C. L. Davis. 1983. Future improvement of milk production: Potential for nutritional improvement. Journal of Dairy Science 57:750-755.

Cochran, R. C., D. C. Adams, P. O. Currie, and B. W. Knapp. 1986. Cubed alfalfa hay or cottonseeed meal-barley as supplement for beef cows grazing fall-winter range. Journal of Range Management 39:361-364.

DelCurto, T., R. C. Cochran, D. L. Harmon, A. A. Beharka, K. A. Jacques, G. Towne, and E. S. Vanzant. 1990a. Supplementation of dormant tallgrass-prairie forage: I. Influence of varying supplemental protein and (or) energy levels on forage utilization characteristics of beef steers in confinement. Journal of Animal Science 68:515-531. 
DelCurto, T., R. C. Cochran, T. G. Nagaraja, L. R. Corah, A. A. Beharka, and E. S. Vanzant. $1990 \mathrm{~b}$. Comparison of soybean meal/sorghum grain, alfalfa hay and dehydrated alfalfa pellets as supplemental protein sources for beef cattle consuming dormant tallgrass-prairie forage. Journal of Animal Science 68:2901-2915.

Erdman, R. A., G. H. Proctor, and J. H. Vandersall. 1986. Effect of rumen ammonia concentration on in situ rate and extent of digestion of feedstuffs. Journal of Dairy Science 69:2312-2320.

Firkins, J. L., L. L. Berger, N. R. Merchen, G. C. Fahey, Jr., and D. R. Nelson. 1986. Effects of feed intake and protein degradability on ruminal characteristics and site of digestion in steers. Journal of Dairy Science 69:21112123.

Galyean, M. L., and F. N. Owens. 1991. Effects of diet composition and level of feed intake on site and extent of digestion in ruminants. In; T. Tsuda, Y. Sasaki, and R. Kawashima (Ed.) Physiological Aspects of Digestion and Metabolism in Ruminants: Academic Press, New York pp 483-574.

Goering, H. K., and P. J. Van Soest. 1970. Forage fiber analyses (apparatus, reagents, procedures, and some applications). Agriculture. Handbook No. 379. ARS, USDA, Washington, D. C.
Goetsch, A. L., and M. L. Galyean. 1983. Influence of feeding frequency on passage of fluid and particulate markers in steers fed a concentrate diet. Canadian Journal of Animal Science 63:727-730.

Gorosito, A. R., J. B. Russell, and P. J. Van Soest. 1985. Effect of carbon-4 and carbon-5 volatile fatty acids on digestion of plant cell wall in vitro. Journal of Dairy Science 68:840-847.

Grisby, K. N., C. W. Peters, M. S. Kerley, and J. A. Paterson. 1991. Digestibility of vegetative and mature tall fescue greenchop with or without alfalfa greenchop substitution. Journal of Animal Science 69:4602-4610.

Gunter, S. A., L. J. Krysl, M. B. Judkins, J. T. Broesder, and R. K. Barton. 1990. Influence of branched-chain fatty acid supplementation on voluntary intake, site and extent of digestion, ruminal fermentation, digesta kinetics and microbial protein synthesis in beef heifers consuming grass hay. Journal of Animal Science 68:2885-2892.

Hannah, S. M., R. C. Cochran, E. S. Vanzant, and D. L. Harmon. 1991. Influence of protein supplementation on site and extent of digestion, forage intake, and nutrient flow characteristics in steers consuming dormant bluestem-range forage. Journal of Animal Science 69:2624-2633. 
Hart, S. P., and C. E. Polan. 1980. Simultaneous extraction and determination of ytterbium and cobalt ethylenediaminetetraacetate complex in feces. Journal of Dairy Science 67:888-892.

Hess, B. W., L. J. Krysl, M. B. Judkins, D. W. Holcombe, J. D. Hess, D. R. Hanks, and S. A. Huber. 1996. Supplemental cracked corn or wheat bran for steers grazing endophyte-free fescue pasture: Effects on live weight gain, nutrient quality, forage intake, particulate and fluid kinetics, ruminal fermentation, and digestion. Journal of Animal Science 74:1116-1125.

Hill, F. W., and D. L. Anderson. 1958. Comparison of metabolizable energy and productive energy determination with growing chicks. Journal of Nutrition 64:587-603.

Hoover, W. H. 1986. Chemical factors involved in ruminal fiber digestion. Journal of Dairy Science 69:2755-2766.

Kang-Meznarich, J. H., and G. A. Broderick. 1981. Effects of incremental urea supplementation on ruminal ammonia concentration and bacterial protein formation. Journal of Animal Science 51:422-431.

Neter, J., W Wasserman, and M. H. Kutner. 1990. Applied Linear Statistical Models. Third ed., Homewood, IL, Irwin, p.37.

Orskov, E. R. 1992. Protein Nutrition in Ruminants. Second edition, Academic Press, Inc., London.

Russell, J. B., J. D. O'Connor, D. G. Fox, P. J. Van Soest and C. J. Sniffen. 1992. A carbohydrate and protein system for evaluating cattle diets: I. Ruminal fermentation. Journal of Animal Science 70:3551-3561.

SAS. 1989. SAS User's Guide: Statistics (Version 6.0, 4th Ed.). SAS Inst., Inc., Cary, NC.

Stafford, S. D., R. C. Cochran, E. S. Vanzant and J. O. Fritz. 1996. Evaluation of the potential of supplements to substitute for low-quality, tallgrass-prairie forage. Journal of Animal Science 74:639-647.

Stafford, S. D., R. C. Cochran, E. S. Vanzant and J. O. Fritz. 1996. Evaluation of the potential of supplements to substitute for low-quality, tallgrass-prairie forage. Journal of Animal Science 74:639-647.
Stefanon, B., A. N. Pell and P. Schofield. 1996. Effect of maturity on digestion kinetics of water soluble and water insoluble fractions of alfalfa and brome hay. Journal of Animal Science 74:1104-1115.

Stern, M. D., H. Hoover, C. J. Sniffen, B. A. Crooker, and P. H. Knowlton. 1978. Effects of nonstructural carbohydrate, urea and soluble protein levels on microbial protein synthesis in continuous culture of rumen contents. Journal of Animal Science 47:944-956.

Stokes, S. R., W. H. Hoover, T. K. Miller, and R. Blauwweikel. 1988. Ruminal digestion and microbial utilization of diets varying in type of carbohydrate and protein. Journal of Dairy Science 74:871-881.

Sunvold, G. D., R. C. Cochran, and E. S. Vanzant. 1991. Evaluation of wheat middlings as a supplement for beef cattle consuming dormant bluestem-range forage. Journal of Animal Science 69:3044-3054.

Teeter, R. G., F. N. Owens, and T. L. Mader. 1984. Ytterbium chloride as a marker for particulate matter in the rumen. Journal of Animal Science 58:465-473.

Uden, P., P. E. Colucci, and P. J. Van Soest. 1980. Investigation of chromium, cerium and cobalt as markers in digesta. Rate of passage studies. Journal of the Science of Food and Agriculture 31:625-632.

Van Soest, P. J. 1994. Nutritional Ecology of the Ruminant. $2^{\text {nd }}$ ed., Cornell University Press, Ithaca, New York,

Williams, C. H., D. J. David and O Iismaa. 1962. The determination of chromic oxide in faeces samples by atomic absorption spectrophotometry. Journal of Agricultural Science (Camb.) 59:381-388.

Whitney, M. B. 1998. Effects of supplemental soybean oil on performance and ruminal fermentation of developing beef heifers. MS Thesis, Department of Animal Science, University of Wyoming, Laramie, WY.

Zinn, R. A. and F. N. Owens. 1986. A rapid procedure for purine measurement and its use for estimating net ruminal protein synthesis. Canadian Journal of Animal Science 66:157-166. 